\title{
DAMPAK KEGIATAN PRODUKTIF DI TAMBANG PASIR TERHADAP ANGKA ANAK PUTUS SEKOLAH PADA JENJANG SMP
}

\author{
Dimas Sulistyo Sunarto', Agus Purnomo², Siti Malikhah Towaf ${ }^{3}$ \\ 1,2,3Program Studi Pendidikan IPS, Universitas Negeri Malang \\ e-mail: agus.purnomo.fis@um.ac.id
}

\begin{abstract}
One type of instant economic activity includes being sand miner and sand transporter in the sand mining area. The purpose of this study is to describe the impact of children's productive activities in the sand mine on dropout rates at the junior high school level in Keduwang Village, Blitar Regency. Respondents of the research data amounted to 38 children who carried out productive activities of sand mining. This study used cross-sectional survey research method with a quantitative approach that were supplemented with qualitative data. The collection technique used questionnaire, observation, and interviews. Data analysis techniques used descriptive data analysis techniques with the odds ratio method. The results indicate that the impact of children's productive activities in sand mining on dropout rates at junior high school level with decrease of children's interest attending school. The results of odd ratio analysis indicate that the riskiest factor causing children to choose school dropout is productive activities in sand mining do not require special skills. The factor of not requiring special skills is proven to be six times the risk of causing children school dropout. The results provide description of how easy economic access and does not require skills has an impact on children's perceptions of going to school or working. Implications for the results of this research are expected to be a reference for government to pay attention to dropout rates that occur due to the productive activities of children in sand mining.
\end{abstract}

Keywords: productive activities, sand mining, school dropout, junior high school

Received: 04 November 2019

Accepted: 20 April 2020

Published: 15 Juni 2020

\section{PENDAHULUAN}

Sumber Daya Alam (SDA) adalah unsur-unsur yang terdiri dari SDA nabati (tumbuhan) dan SDA hewani (satwa) dengan unsur non hayati di sekitarnya yang secara keseluruhan membentuk ekosistem (KEHATI, 2009). Setiap wilayah di muka bumi memiliki potensi sumber daya alam yang berbeda-beda. Indonesia merupakan salah satu negara di dunia yang kaya akan sumber daya alam, baik sumber daya alam hayati maupun non hayati. Hal ini menjadi salah satu keunggulan apabila sumber daya alam yang ada dimanfaatkan secara optimal. Salah satu sumber daya alam yang ada di Indonesia ada di sektor pertambangan. Mulai dari pertambangan emas, batu bara, dan pasir.

Kabupaten Blitar merupakan salah satu kabupaten di Provinsi Jawa Timur yang memiliki potensi mineral non logam, hal tersebut dibuktikan dengan adanya lokasi penambangan pasir (Dinas Energi dan Sumber Daya Provinsi Jawa Timur, 
2016). Penambangan adalah bagian kegiatan usaha pertambangan untuk memproduksi mineral dan/atau batu bara dan mineral ikutannya. Pertambangan mineral adalah pertambangan kumpulan mineral yang berupa bijih atau batuan, di luar panas bumi, minyak dan gas bumi, serta air tanah (Salim, 2014).

Penambangan pasir adalah penggalian di bawah permukaan tanah baik di lahan ataupun di bawah tanah aliran sungai dengan maksud pengambilan jenis bahan galian mineral non logam berupa pasir yang mempunyai arti ekonomis (Salim, 2014). Lokasi penambangan pasir di Kabupaten Blitar bisa ditemui di sepanjang aliran lahar dingin Gunung Kelud. Di antaranya terdapat di Sungai Lekso, Sungai Semut, Bladak, dan Sungai di Desa Kedawung (Badan Perencanaan Pembangunan Daerah Provinsi Jawa Timur, 2013). Desa Kedawung merupakan salah satu desa yang memiliki sungai yang dialiri oleh lahar dingin Gunung Kelud. Penambangan pasir yang dilakukan oleh masyarakat di Desa Kedawung termasuk dalam kategori bahan tambang golongan $\mathrm{C}$ yaitu bahan tidak strategis dan tidak vital. Bahan tambang golongan $\mathrm{C}$ adalah bahan yang dianggap tidak langsung mempengaruhi hajat hidup orang banyak, contohnya garam, batu, pasir, marmer, batu kapur, dan asbes (Undang-undang nomor 4 Tahun 2009 tentang Pertambangan Mineral dan Batubara). Pertambangan pasir di Desa Kedawung dapat dikategorikan sebagai pertambangan rakyat, pertambangan rakyat adalah suatu usaha pertambangan bahan-bahan galian dari semua golongan $\mathrm{A}, \mathrm{B}$, dan $\mathrm{C}$ yang dilakukan oleh rakyat setempat secara kecil-kecilan atau secara gotong royong dengan alat-alat sederhana (Salim, 2014).

Mudahnya menjadi penambang pasir tradisional membuat banyak warga yang memilih menjadi penambang pasir karena tidak mempunyai alternatif lain atau tidak mempunyai keterampilan untuk mencari pekerjaan di luar menambang (Suhartini, 2006). Berdasarkan hasil wawancara awal yang dilakukan oleh peneliti di Desa Kedawung, Kecamatan Nglegok, Kabupaten Blitar teridentifikasi alasan warga sekitar memilih menjadi penambang karena latar belakang pendidikan yang rendah. Menjadi penambang pasir tradisional tidak perlu memiliki pendidikan yang tinggi hanya memerlukan tenaga yang kuat dan peralatan seadanya. Selain itu faktor ekonomi juga mempengaruhi minat warga untuk beralih profesi, bisa dilihat bahwa kebanyakan warga desa yang menjadi penambang adalah anak-anak. Banyak warga desa yang masih anak-anak memilih putus sekolah hanya sampai jenjang Sekolah Menengah Pertama (SMP).

Banyak warga desa yang masih anak-anak memilih putus sekolah hanya sampai jenjang Sekolah Menengah Pertama (SMP) dan akhirnya memutuskan menjadi penambang. Senada dengan hal tersebut Kusumawati \& Utami (2013) menyatakan bahwa sebagian besar para penambang pasir dapat bersekolah sampai jenjang pendidikan dasar. Faktor yang mempengaruhi anak-anak tidak melanjutkan sebuah lembaga pendidikan formal yakni disebabkan oleh faktor kondisi ekonomi keluarga yang tidak memadai (Musfiqon, 2007). Hal tersebut sesuai dengan data yang menunjukkan bahwa 60\% dari anak yang tidak bersekolah di desa Kedawung rata-rata berusia 16-18 tahun akhirnya memutuskan menjadi penambang (Basis Data Terpadu untuk Program Perlindungan Sosial, 2016).

Penelitian berkaitan dengan penambangan sudah ada beberapa hasil kajian oleh penelitian terdahulu. Penelitian terdahulu yang berkaitan dengan penelitian 
ini dilakukan oleh Ma'arif (2016) yang menunjukkan hasil penelitian tentang adanya manfaat ekonomi di sektor tambang menjadi pemicu warga untuk memilih bekerja di tambang pasir. Latar belakang pendidikan warga yang bekerja di tambang merupakan pendidikan dasar jenjang Sekolah Dasar (SD) dan SMP. Warga lebih memilih untuk putus sekolah dan bekerja di tambang pasir dikarenakan pendapatan yang sudah pasti.

Penelitian selanjutnya dilakukan Aristin (2015) yang mana hasil penelitian ini menunjukkan ada tiga faktor yang mempengaruhi anak putus sekolah yaitu faktor ekonomi, faktor sosial, dan faktor fisik. Faktor ekonomi di sini karena tidak adanya biaya, faktor sosial dikarenakan memilih untuk menikah, dan faktor fisik dikarenakan jarak tempat tinggal ke sekolah. Penelitian terdahulu selanjutnya adalah penelitian dari Rahmia (2017) hasil penelitian menunjukkan keluwesan untuk bekerja sebagai penambang pasir, buruh angkut pasir, sopir truk, dan pemilik galangan pasir. Membuat banyak warga memilih untuk tidak melanjutkan pendidikan sehingga berpendidikan rendah. Akan tetapi penelitian-penelitian terdahulu tersebut belum mengkaji lebih dalam tentang dampak kegiatan produktif anak pada pertambangan pasir terhadap angka putus sekolah jenjang SMP di Desa Kedawung, Kecamatan Nglegok, Kabupaten Blitar. Hasil dari riset ini diharapkan mampu memberikan kontribusi tentang dampak kegiatan produktif anak pada pertambangan pasir terhadap angka putus sekolah di jenjang SMP.

\section{METODE PENELITIAN}

Pendekatan yang digunakan dalam penelitian ini adalah pendekatan kuantitatif. Jenis penelitian yang digunakan dalam penelitian ini adalah desain survei cross-sectional yang menjelaskan hubungan antara variabel-variabel di mana X (Kegiatan Produktif) dan Y (Angka Putus Sekolah) (Singarimbun \& Effendi, 2006). Tipe penelitian tersebut sesuai untuk penelitian ini sehingga dapat melihat adanya pengaruh faktor-faktor penyebab anak putus sekolah pada jenjang sekolah menengah pertama sebagai akibat melakukan kegiatan produktif di tambang pasir di Desa Kedawung, Kecamatan Nglegok, Kabupaten Blitar. Responden data penelitian berjumlah 38 anak yang melakukan kegiatan produktif penambangan pasir di Desa Kedawung, Kecamatan Nglegok, Kabupaten Blitar. Peneliti menggunakan teknik incidental random sampling dengan cara melakukan pengambilan data pada setiap anak-anak yang ditemui dan sedang melakukan penambangan pasir di lokasi penelitian.

Teknik pengumpulan data dalam penelitian ini dilakukan dengan metode angket yang diperkuat dengan teknik observasi dan wawancara. Angket merupakan teknik pengumpulan data yang dilakukan dengan cara memberi seperangkat pertanyaan atau pernyataan tertulis kepada responden untuk dijawabnya (Sugiyono, 2017). Angket yang digunakan dalam penelitian di sini adalah angket tertutup. Angket tertutup sendiri adalah angket dengan pertanyaan dalam bentuk kalimat positif dan negatif agar responden dalam memberikan jawaban setiap pertanyaan lebih serius dan tidak mekanis (Sugiyono, 2017). Di mana terdiri dari dua variabel yaitu kegiatan produktif anak dan angka putus sekolah. Indikator dari variabel kegiatan produktif terdiri dari jenis kegiatan produktif yang dilakukan anak. Variabel angka putus sekolah terdiri dari angka putus sekolah jenjang Sekolah Menengah Pertama, dan faktor-faktor penyebab 
putus sekolah. Angket disebarkan kepada anak yang terlibat dalam kegiatan produktif di penambangan pasir di Desa Kedawung yang semuanya sebagai responden yang akan mendapatkan angket

Observasi diartikan sebagai pengamatan dan pencatatan secara sistematik terhadap gejala yang tampak pada objek penelitian (Nawawi, 2012). Observasi ini dilakukan saat peneliti mengikuti kegiatan-kegiatan produktif yang dilakukan anak di penambangan pasir Desa Kedawung. Penelitian ini menggunakan observasi non partisipan dengan cara observasi terstruktur dengan menentukan pengamatan yang dilakukan adalah mengamati kegiatan produktif anak yang dilakukan di penambangan pasir Desa Kedawung Kecamatan Nglegok Kabupaten Blitar. Tujuan observasi dalam penelitian ini adalah meninjau kegiatan produktif apa saja yang dilakukan oleh anak di penambangan pasir Desa Kedawung.

Wawancara adalah tanya jawab lisan antara dua orang atau lebih secara langsung (Akbar \& Usman, 2009). Wawancara yang digunakan pada penelitian ini adalah wawancara tidak terstruktur. Wawancara tidak terstruktur cocok digunakan untuk mendapat data lebih mendalam serta digunakan sebagai sarana konfirmasi jawaban responden atas pernyataan angket yang telah diisi.

Teknik analisis data yang digunakan pada penelitian ini adalah statistik deskriptif. Peneliti menggunakan analisis tabulasi silang, tabulasi tunggal, dan juga odd ratio analysis. Tabulasi silang digunakan untuk melihat kecenderungan antar dua variabel (Widarsa \& Ekaputra, 2006). Analisis odds ratio (OR) dalam penelitian ini digunakan untuk mengetahui ada atau tidaknya dampak variabel X (Kegiatan Produktif) terhadap variabel Y (Angka Putus Sekolah) secara deskriptif. Odds ratio dalam penelitian ini digunakan untuk memprediksi risiko yang akan terjadi pada masa mendatang pada pola hubungan antar dua variabel. Analisis ini juga memudahkan peneliti untuk menarik kesimpulan tentang faktor-faktor penyebab anak putus sekolah pada jenjang sekolah menengah pertama sebagai akibat melakukan kegiatan produktif penambangan pasir di Desa Kedawung, Kecamatan Nglegok, Kabupaten Blitar. Selain itu untuk memperkuat hasil angket peneliti juga menambahkan hasil pengumpulan data dari observasi dan juga wawancara mendalam sebagai cara mengonfirmasi hasil pengisian angket oleh responden.

\section{HASIL PENELITIAN DAN PEMBAHASAN}

\section{Kegiatan Produktif Anak-anak di Pertambangan Pasir Desa Kedawung, Kecamatan Nglegok, Kabupaten Blitar}

Berdasarkan hasil observasi dan wawancara pada anak-anak yang melakukan kegiatan produktif di pertambangan pasir Desa Kedawung, menunjukkan bahwa terdapat tiga jenis kegiatan produktif yang dilakukan anak-anak di pertambangan pasir Desa Kedawung yaitu sebagai penambang pasir, kuli angkut, dan penjaga portal. Hasil penelitian ini menguatkan serta melengkapi hasil penelitian yang dilakukan oleh Rahmia (2017) yang menyatakan bahwa ada beberapa jenis pekerjaan di tambang pasir di antaranya adalah menjadi penambang pasir dan juga kuli angkut pasir.

Berdasarkan hasil observasi dan wawancara di area tambang pasir Desa Keduwang teridentifikasi bahwa anak-anak yang melakukan kegiatan produktif di pertambangan pasir didominasi oleh anak yang memilih putus sekolah atau berhenti antar jenjang pada tingkat Sekolah Menengah Pertama (SMP). Bagoe 
(2013) mengemukakan bahwa putus sekolah atau berhenti antara jenjang adalah putus sekolah di mana peserta didik berhenti antara jenjang dan tidak melanjutkan pelajaran ke tingkat yang lebih tinggi. Hal itu selaras dengan hasil penelitian Ma'arif (2016) di mana latar pendidikan warga yang bekerja tambang pasir adalah pendidikan dasar (SD dan SMP) dikarenakan warga lebih memilih untuk putus sekolah dan bekerja di tambang pasir dikarenakan pendapatan yang sudah pasti.

Hasil penelitian Aristin (2015) mengemukakan bahwa ada tiga faktor yang mempengaruhi anak putus sekolah yaitu faktor ekonomi, faktor sosial, dan faktor fisik. Berdasarkan hasil wawancara pada anak-anak di Desa Keduwang terdapat tiga faktor yang menyebabkan mereka putus sekolah dan terlibat kegiatan produktif pertambangan pasir yaitu tidak ada biaya, tidak ada keinginan melanjutkan ke pendidikan selanjutnya, dan faktor pengaruh teman sebaya. Di antara ketiga faktor tersebut faktor yang paling dominan adalah faktor tidak ada biaya. Bagoe (2013) menjelaskan bahwa kurangnya pendapatan keluarga menyebabkan orang tua bekerja keras mencukupi kebutuhan sehari-hari sehingga perhatian orang tua terhadap pendidikan cenderung terabaikan. Kurangnya perhatian orang tua terhadap pendidikan anak berpengaruh terhadap cara orang tua memenuhi kebutuhan - kebutuhan anak dalam belajar di rumah maupun di sekolah.

Berdasarkan hasil pengamatan yang dilakukan peneliti di Desa Kedawung menunjukkan bahwa kegiatan produktif anak di tambang pasir dibagi menjadi dua jenis prioritas yaitu ada yang dijadikan sebagai pekerjaan utama dan ada juga yang merupakan pekerjaan sampingan. Maksud dari kegiatan produktif sebagai pekerjaan utama yaitu kegiatan produktif dijadikan sebagai pekerjaan utama bagi anak-anak tambang pasir yang memang tidak memiliki pekerjaan lain. Sedangkan yang dimaksud dengan pekerjaan sampingan adalah anak-anak tambang pasir yang menjadikan kegiatan produktif di tambang pasir hanya sebagai sampingan karena memiliki pekerjaan utama di antaranya menjadi tukang bangunan maupun bekerja di peternakan yang banyak terdapat di Desa Kedawung.

\section{Faktor-faktor yang Mempengaruhi Anak-anak Desa Kedawung untuk Memilih Bekerja di Tambang Pasir}

Berikut disajikan tabel 1, 2, dan 3 yang merupakan hasil jawaban responden dari angket yang telah diisi oleh 38 anak-anak di tambang pasir Desa Kedawung.

Tabel 1.

Alasan Ketertarikan Bekerja di Tambang Pasir dengan Lanjut Tidak Sekolah Crosstabulation

\begin{tabular}{lcccc}
\hline & $\begin{array}{c}\text { Alasan Ketertarikan Bekerja } \\
\text { Ni Tambang Pasir }\end{array}$ & \multicolumn{2}{c}{ Lanjut Tidak Sekolah } & \\
\cline { 3 - 5 } No. & & $\begin{array}{c}\text { Melanjutkan } \\
\text { Tetap Bekerja di } \\
\text { Tambang Pasir }\end{array}$ & $\begin{array}{c}\text { Pendidikan } \\
\text { Kembali }\end{array}$ & Total \\
\hline 1. & Kemudahan dalam bekerja & 15 & 11 & 26 \\
2. & Penghasilan yang cukup & 6 & 6 & 12 \\
\hline & Total & 21 & 17 & 38 \\
\hline
\end{tabular}


Tabel 2.

Informasi Adanya Peluang Kegiatan Produktif Ditambang Pasir dengan Lanjut Tidak Sekolah Crosstabulation

\begin{tabular}{lcccc}
\hline & $\begin{array}{c}\text { Alasan Memilih Bekerja di } \\
\text { Nambang Pasir daripada } \\
\text { Pekerjaan Lain }\end{array}$ & \begin{tabular}{c} 
Lanjut Tidak Sekolah \\
Tetap Bekerja di \\
\cline { 3 - 4 }
\end{tabular} & $\begin{array}{c}\text { Melanjutkan } \\
\text { Tambang Pasir }\end{array}$ & $\begin{array}{c}\text { Pendidikan Kembali } \\
\text { Total }\end{array}$ \\
\hline 1. & Kemudahan dalam bekerja & 15 & 11 & 26 \\
2. & Penghasilan yang cukup & 6 & 6 & 12 \\
\hline & Total & 21 & 17 & 38 \\
\hline
\end{tabular}

Berdasarkan hasil angket pada tabel 1 maupun tabel 2 tersebut dan didukung dengan hasil wawancara yang dilakukan teridentifikasi dua alasan utama anak memilih bekerja di pertambangan pasir daripada bekerja pada sektor lain yaitu kemudahan cara maupun akses untuk bekerja dan penghasilan yang cukup. Selain itu berdasarkan hasil wawancara lebih dalam terdapat faktor lain yang mempengaruhi yaitu kegiatan produktif pertambangan pasir tidak memerlukan keterampilan khusus dalam arti memang sesuai dengan kemampuan anak-anak pada kegiatan produktif tersebut.

Alasan karena kemudahan dalam bekerja menjadi alasan yang dominan berdasarkan jawaban dari anak-anak Desa Kedawung. Kemudahan merupakan tingkat di mana seseorang meyakini apa yang dilakukan merupakan sesuatu hal yang tidak sulit untuk dipahami dan tidak memerlukan usaha keras untuk bisa melakukannya. Konsep kemudahan memberikan pengertian bahwa apabila suatu usaha mudah dilakukan, maka orang cenderung memilih untuk melakukan hal tersebut (Afifah, 2017). Bekerja di tambang pasir dengan cara tradisional memang memberikan kemudahan dalam bekerja karena hanya membutuhkan alat sederhana. Maksud dari cara tradisional di sini adalah dilakukan dengan menggunakan peralatan sederhana, seperti penggunaan cangkul, linggis, palu, dan keranjang bambu (Utama, 2018).

Kegiatan produktif sebagai penambang pasir merupakan jenis kegiatan produktif yang paling banyak dipilih oleh anak-anak di Desa Kedawung karena memiliki penghasilan yang paling tinggi dibanding jenis kegiatan produktif lain di pertambangan pasir. Penambang pasir merupakan kegiatan produktif yang dilakukan secara berkelompok atau tim dengan menggunakan peralatan sederhana seperti cangkul, sekop, dan juga linggis. Selain menjadi penambang pasir ada jenis kegiatan produktif lain di sektor pertambangan pasir yang dipilih oleh anak yaitu menjadi kuli angkut pasir dan juga penjaga portal. Namun, dua jenis kegiatan produktif tersebut kurang diminati karena memiliki penghasilan yang lebih rendah dibanding menjadi penambang pasir. Definisi dari penghasilan yang rendah yaitu pendapatan atau penerimaan sebagai imbalan terhadap kerja mereka yang jumlahnya jauh lebih sedikit apabila dibandingkan dengan kebutuhan pokok (Sumardi \& Evers, 2002). Besar penghasilan menjadi kuli angkut pasir tergantung dari seberapa sering jasa mereka digunakan begitu pula menjadi penjaga portal penghasilan tergantung dari seberapa sering sopir truk memberi uang bonus ketika keluar dari area tambang pasir. Hal tersebut menjadikan 
kegiatan kuli angkut dan penjaga portal penghasilannya menjadi tidak menentu dibandingkan dengan kegiatan penambang pasir.

Selain itu, alasan kesesuaian dengan kemampuan adalah alasan dominan muncul pula berdasarkan pada hasil jawaban dari anak-anak di Desa Kedawung. Robbins (2002) mengemukakan kemampuan (ability) adalah kapasitas individu untuk melaksanakan berbagai tugas dalam pekerjaan tertentu. Selaras dengan definisi tersebut alasan sesuai dengan kemampuan dikarenakan anak-anak di Desa Kedawung pada dasarnya belum memiliki banyak keterampilan apalagi dengan latar belakang pendidikan yang hanya sampai pendidikan dasar sehingga mendorong anak-anak untuk memilih kegiatan-kegiatan produktif di pertambangan pasir yang tidak memerlukan keterampilan khusus.

Tabel 3.

Informasi Adanya Peluang Kegiatan Produktif di Tambang Pasir dengan Lanjut Tidak Sekolah Crosstabulation

\begin{tabular}{|c|c|c|c|c|}
\hline \multirow[b]{2}{*}{ No. } & \multirow{2}{*}{$\begin{array}{c}\text { Informasi Adanya } \\
\text { Peluang Kegiatan } \\
\text { Produktif di Tambang } \\
\text { Pasir }\end{array}$} & \multicolumn{2}{|c|}{ Lanjut Tidak Sekolah } & \multirow[b]{2}{*}{ Total } \\
\hline & & $\begin{array}{l}\text { Tetap Bekerja di } \\
\text { Tambang Pasir }\end{array}$ & $\begin{array}{c}\text { Melanjutkan } \\
\text { Pendidikan Kembali }\end{array}$ & \\
\hline 1. & Teman & 11 & 11 & 22 \\
\hline 2. & Pengetahuan sendiri & 10 & 6 & 16 \\
\hline & Total & 21 & 17 & 38 \\
\hline
\end{tabular}

Pada tabel 3 menunjukkan bahwa anak-anak di Desa Kedawung mayoritas mendapat informasi tentang peluang kegiatan produktif di tambang pasir yaitu dari teman sebaya dan juga anak-anak ternyata sudah mengetahui secara mandiri tentang peluang kegiatan produktif tersebut. Hasil tersebut sesuai dengan penelitian Kamsihyanti, Sutomo, \& Shalihati (2016) yang menyatakan faktor lingkungan masyarakat yaitu lingkungan masyarakat tempat anak tinggal yang mayoritas berpendidikan rendah dan teman-teman bermain di sekitar tempat tinggal sudah tidak melanjutkan sekolah berpengaruh dominan sebagai penyebab anak putus sekolah serta memilih bekerja.

Faktor-faktor yang dapat dilihat pada tabel 1, 2, dan 3 tersebut mempengaruhi penurunan minat anak untuk melanjutkan ke pendidikan selanjutnya. Khadijah, Indrawati, \& Suarman (2017) mengemukakan minat anak melanjutkan ke pendidikan selanjutnya tergolong rendah dikarenakan salah satu faktor penghambatnya adalah dari segi status sosial ekonomi orang tua. Faktor status sosial ekonomi orang tua berperan penting dalam kelanjutan pendidikan anak. Anak yang berasal dari keluarga dengan ekonomi yang cukup, mempunyai kesempatan yang lebih luas untuk mengembangkan kemampuannya melalui pendidikan tinggi dibandingkan anak yang berasal dari keluarga yang ekonominya rendah (Khadijah, Indrawati, \& Suarman, 2017).

Berikut tabel hasil analisis odd ratio tentang alasan yang paling berisiko menjadi faktor penyebab anak-anak Desa Kedawung memilih putus sekolah. 
Tabel 4.

Hasil Analisis Odd Ratio

\begin{tabular}{llc}
\hline No & \multicolumn{1}{c}{ Variabel } & $\begin{array}{c}\text { Nilai Risiko Anak Memilih Putus } \\
\text { Sekolah }\end{array}$ \\
\hline 1 & Tidak membutuhkan keterampilan & $6 \mathrm{x}$ \\
& khusus & $5 \mathrm{x}$ \\
2 & Kemudahan dalam bekerja & 0,3 \\
3 & Penghasilan yang cukup & $2 \mathrm{x}$ \\
4 & Faktor lingkungan & \\
\hline
\end{tabular}

Berdasarkan hasil analisis menggunakan odd ratio menunjukkan bahwa alasan yang paling berisiko menjadi faktor penyebab anak putus sekolah adalah dikarenakan kegiatan produktif anak di tambang pasir tidak memerlukan keterampilan khusus. Faktor tersebut berisiko 6x membuat anak memilih putus sekolah. Kadarisman (2012) menerangkan bahwa skills (keterampilan) pekerja merupakan salah satu faktor dalam usaha mencapai suksesnya pencapaian tujuan pekerjaan. Tidak dibutuhkannya keterampilan yang khusus membuat anak memilih pekerjaan di sektor tambang pasir daripada pada sektor lain.

\section{KESIMPULAN}

Berdasarkan hasil penelitian dapat disimpulkan bahwa ada tiga jenis kegiatan produktif anak di tambang pasir yaitu menjadi penambang pasir, kuli angkut, dan penjaga portal. Di mana menjadi penambang pasir adalah jenis kegiatan produktif yang paling banyak diminati. Alasan yang paling dominan membuat anak memilih bekerja di tambang pasir daripada di sektor lain adalah karena kegiatan produktif di tambang pasir tidak memerlukan keterampilan khusus. Faktor yang mempengaruhi anak putus sekolah adalah karena tidak ada biaya, hal tersebut membuat anak tertarik untuk melakukan kegiatan produktif ditambang pasir karena kemudahan dalam bekerja. Kemudahan tersebut membuat anak memilih untuk menjadikan kegiatan produktif di tambang pasir menjadi pekerjaan utama. Sehingga menurunkan minat anak untuk melanjutkan kependidikan selanjutnya sehingga lebih memilih bekerja ditambang pasir.

Hasil dari analisis odd ratio dalam penelitian ini menunjukkan bahwa faktor paling berisiko menyebabkan anak memilih putus sekolah adalah karena tidak memerlukan keterampilan khusus. Faktor tidak memerlukan keterampilan khusus terbukti 6 kali berisiko menyebabkan anak putus sekolah. Keterbatasan dari riset yang dilakukan hanya berfokus pada faktor-faktor penyebab anak putus sekolah pada jenjang SMP sebagai akibat kegiatan produktif di tambang pasir Desa Kedawung, Kecamatan Nglegok, Kabupaten Blitar. Peran orang tua dalam penelitian ini hanya digunakan sebagai validator hasil survei dari anak yang terlibat kegiatan produktif di tambang pasir. Rekomendasi untuk riset dimasa mendatang untuk melakukan penelitian dengan menggunakan perspektif yang berbeda misalnya mengenai peran serta orang tua terhadap keterlibatan anak pada kegiatan produktif di tambang pasir. Selanjutnya, penelitian ini diharapkan dapat dijadikan referensi untuk penelitian selanjutnya. 


\section{DAFTAR PUSTAKA}

Afifah, R. 2017. Pengaruh Manfaat, Kemudahan, Kepercayaan dan Ketersediaan Fitur Terhadap Penggunaan Mobile Banking Syariah Mandiri. Skripsi. Jakarta: Universitas Islam Negeri Syarif Hidayatullah.

Akbar, P.S. \& Usman, H. 2009. Metode Penelitian Sosial. Jakarta: Bumi Aksara.

Aristin, N.F., 2015. Faktor-Faktor yang Berpengaruh terhadap Anak Putus Sekolah Tingkat Sekolah Menengah Pertama (SMP) di Kecamatan Bondowoso. Jurnal Pendidikan Geografi. 20 (1), 30-36. DOI: https://doi.org/10.17977/um017v20i12015p030.

Badan Perencanaan Pembangunan Daerah Provinsi Jawa Timur. 2013. Jurnal Potensi Kabupaten dan Kota Blitar.

Bagoe, R. 2013. Faktor-Faktor Penyebab Anak Putus Sekolah di Desa Suka Damai Kecamatan Bulango Utara Kabupaten Bone Bolango. Skripsi. Gorontalo: Universitas Negeri Gorontalo.

Basis Data Terpadu untuk Program Perlindungan Sosial. 2016. Basis Data Terpadu Untuk Program Perlindungan Sosial.

Dinas Energi dan Sumber Daya Provinsi Jawa Timur. 2016. Jurnal Daerah Galian Non Logam.

Kadarisman, M. 2012. Manajemen Pengembangan Sumber Daya Manusia. Jakarta: Raja Grafindo Persada.

Kamsihyati, T., Sutomo, \& Shalihati, F.S. 2016. Kajian Faktor-Faktor Penyebab Anak Putus Sekolah di Desa Jangrana Kecamatan Kesugihan Kabupaten Cilacap. Geo Edukasi, 5 (1), 16 - 21.

KEHATI, 2009. Materi Kursus Inventarisasi Flora dan Fauna Taman Nasional Meru Betiri. Malang.

Khadijah, S., Indrawati, H., \& Suarman. 2017. Analisis Minat Peserta Didik untuk Melanjutkan Pendidikan Tinggi. Jurnal Pendidikan Ilmu Sosial, 26 (2), 178188.

Kusumawati, R. \& Utami, W.S. 2013. Dampak Kegiatan Penambangan Pasir terhadap Kondisi Sosial Ekonomi Keluarga Penambang di Kecamatan Kepung Kabupaten Kediri. Jurnal Online Program Studi S-1 Pendidikan Geografi - Fakultas Ilmu Sosial UNESA, 1-5. 
Ma'arif, C. 2016. Karakteristik Sosial Ekonomi Penambang Pasir Di Desa Poncowarno Kecamatan Kalirejo Kabupaten Lampung Tengah Tahun 2016. Skripsi. Lampung: Universitas Lampung.

Menteri Hukum dan HAM Republik Indonesia. 2009. Undang-Undang No. 4 tahun 2009 tentang Pertambangan Mineral dan Batubara.

Musfiqon, 2007. Menangani yang Putus Sekolah. Sidoarjo: UMSIDA Press.

Nawawi, H. 2012. Metode Penelitian Bidang Sosial. Yogyakarta: Gajah Mada University Press.

Rahmia, S.H. 2017. Kondisi Sosial Penambang Pasir Kali Putih Warga Desa Karangrejo dan Desa Sidodadi Kabupaten Blitar. Skripsi. Malang: Univesitas Negeri Malang.

Robbins, S.P. 2002. Prinsip-Prinsip Perilaku Organisasi. Edisi Kelima. Jakarta: Erlangga.

Salim, H.S. 2014. Hukum Pertambangan Mineral dan Batubara. Jakarta: Sinar Grafika.

Singarimbun, M. \& Effendi, S. 2006. Metode Penelitian Survei. Jakarta: LP3ES.

Sugiyono, 2017. Metode Penelitian Kuantiatif, Kualitatif, dan R\&D. Bandung: Alfabeta.

Suhartini, 2006. Fenomena Penambangan Pasir dan Pembangunan Beserta Dampak Lingkungan yang Ditimbulkannya (Studi Kasus di Sekitar Merapi dan di Kabupaten Bantul). Seminar Nasional MIPA 2006, Fakultas Matematika dan Ilmu Pengetahuan Alam, UNY, Yogyakarta

Sumardi, M. \& Evers, H.D. 2002. Kemiskinan dan Kebutuhan Pokok. Jakarta: Rajawali.

Utama, R. 2018. Kondisi Sosial Penambang Pasir di Sungai Mujur Desa Gesang Kecamatan Tempeh Kabupaten Lumajang. Skripsi. Malang: Univesitas Negeri Malang.

Widarsa, I. K.T. \& Ekaputra, I.W.G.A. 2006. Analisis Data untuk Variabel Outcome Berskala Nominal Dua Kategori (Binary Outcome). Denpasar: Universitas Udayana. 